\title{
BioLink
}

Jurnal Biologi Lingkungan, Industri, Kesehatan

Available online http://ojs.uma.ac.id/index.php/biolink

\section{PENGARUH RADIASI PLASMA DAN PUPUK KANDANG KAMBING TERHADAP PERTUMBUHAN BAWANG MERAH VARIETAS BIMA BREBES}

\section{THE EFFECT OF PLASMA RADIATION AND GOAT FERTILIZER ON GROWTH OF SHALLOT VARIETY OF BIMA BREBES}

\author{
Emi Anitasari ${ }^{*}{ }^{*}$, Erma Prihastanti ${ }^{1}$, dan Fajar Arianto ${ }^{2}$ \\ ${ }^{1}$ Departemen Biologi, Fakultas Sains dan Matematika, Universitas Diponegoro, Indonesia \\ 2 Departemen Fisika, Fakultas Sains dan Matematika, Universitas Diponegoro, Indonesia
}

Diterima : 17-06-2019; Disetujui : 10-12-19: Diterbitkan : 10-02-2020

*Corresponding author: E-mail: eprihast@yahoo.co.id

\begin{abstract}
Abstrak
Bawang merah varietas Bima Brebes merupakan varietas bawang merah yang banyak dibudidayakan oleh petani di Indonesia karena mudah tumbuh dan beradaptasi dengan lingkungan setempat. Akan tetapi pada kenyataannya banyak petani yang menggunakan hasil panen sebelumnya untuk bibit tanam berikutnya sehingga hasil panen yang didapatkan akan memiliki kualitas yang kurang baik. Penelitian ini bertujuan untuk mengetahui adanya pengaruh pemberian nitrogen melalui plasma lucutan pijar korona dan pupuk kandang kambing terhadap pertumbuhan bawang merah sehingga bisa meningkatkan kualitas bibit bawang merah. Penelitian ini menggunakan Rancangan Acak Lengkap (RAL) dengan pola faktorial yang menggunakan faktor plasma lucutan pijar korona dan pupuk kandang kambing. Hasil penelitian menunjukkan adanya hubungan interaksi dari kedua faktor yang dapat dilihat dari parameter tinggi tanaman yang memperlihatkan hasil yang signifikan pada perlakuan bibit tanaman yang di radiasi plasma selama 30 menit dan media tanamnya diberi pupuk kandang kambing $65 \mathrm{~g}$. Berdasarkan hasil penelitian dapat disimpulkan bahwa pemberian plasma lucutan pijar korona dan pupuk kandang kambing pada budidaya tanaman bawang merah varietas Bima Brebes mampu mempercepat waktu tumbuh tunas sebesar $200,3 \%$ dan meningkatkan pertumbuhan tanaman bawang merah.
\end{abstract}

Kata Kunci: bawang merah lokal, plasma lucutan pijar korona, pupuk kandang kambing, pertumbuhan tanaman

\begin{abstract}
Shallot variety of Bima Brebes is a shallot variety that is widely cultivated by farmers in Indonesia because it is easy to grow and adapt to the local environment. However, in reality, many farmers use the previous harvest for the next planting seed so that the yields obtained will be of poor quality. This study aims to determine the effect of giving nitrogen through corona incandescent plasma discharge and goat fertilizer on the growth of shallots so that it can improve the quality of onion seedlings. This study used a Completely Randomized Design (CRD) with a factorial pattern using a corona incandescent plasma discharge factor and goat manure. The results showed an interaction between the two factors that can be seen from the plant height parameters which showed significant results in the treatment of plant seeds that were plasma radiation for 30 minutes and the planting media were given goat manure $65 \mathrm{~g}$. Based on the results of the study it can be concluded that the administration of corona incandescent plasma discharge and goat manure on the cultivation of shallots varieties of Bima Brebes was able to accelerate the time of sprouting by $200.3 \%$ and increase the growth of onion plants.
\end{abstract}

Key Words: local shallot, corona incandescent plasma discharge, goat fertilizer, plant growth

How to Cite: Anitasari, E., Prihastanti, E., dan Arianto, F. (2020). Pengaruh Radiasi Plasma dan Pupuk Kandang Kambing Terhadap Pertumbuhan Bawang Merah Varietas Bima Brebes, BioLink: Jurnal Biologi Lingkungan, Industri dan Kesehatan, Vol.6 (2): Hal. 114-125 
Anitasari, E., Prihastanti, E., dan Arianto, F. Pengaruh Radiasi Plasma dan Pupuk andang Kambing Pertumbuhan Bawang Merah Varietas Bima Brebes

PENDAHULUAN

Bawang merah menjadi salah satu komoditas bahan pokok yang harganya sangat fluktuatif. Hal ini dapat dilihat dari lonjakan harga bawang merah yang terjadi di daerah - daerah yang tidak stabil mulai dari Rp 20.000/kg sampai Rp. 26.000/kg (Kemendag, 2019). Selama enam tahun terakhir produksi bawang merah menunjukkan data yang fluktuatif yaitu dengan rata-rata produktivitas bawang merah di Indonesia hanya mencapai 9,31 ton/ha. Sedangkan untuk luas panen dan jumlah produksi bawang merah yaitu sebesar 158,172 ha dan $1,470,155$ ton (Direktorat Jenderal Hortikultura, 2018).

Salah satu unsur penunjang keberhasilan usaha produksi bawang merah (Allium cepa L.) adalah penggunaan benih bermutu. Benih merupakan komponen yang meningkatkan produksi bawang merah. Oleh karena itu pemilihan varietas diprioritaskan yaitu pada perbaikan hasil, daya tahan terhadap hama dan penyakit, dan memiliki adaptasi tinggi terhadap agroekosistem wilayah setempat (Erytrina, 2013).

Rendahnya produktivitas bawang merah dipengaruhi beberapa faktor antara lain iklim, teknik budidaya, penggunaan varietas, dan serangan hama dan penyakit. Selain itu juga dipengaruhi oleh produktivitas tanah pada lahan pertanian tanaman bawang merah yang semakin hari semakin menurun yang disebabkan oleh penggunaan pupuk anorganik yang berlebihan yang berdampak pada kerusakan struktur tanah. Oleh karena itu diperlukan pupuk organik berkualitas tinggi untuk meningkatkan hasil produksi tanaman (Nana \& Salamah, 2014 ; Darwis 2004).

Bibit bawang merah lokal (Allium cepa L.) memiliki kelemahan dalam pertumbuhannya sehingga menyebabkan petani lebih memilih untuk mengembangkan varietas asal impor. Varietas bawang merah impor memiliki ciri yaitu ukurannya lebih besar, kandungan airnya lebih banyak dan warnanya lebih pucat, serta aromanya jauh lebih rendah dibandingkan dengan bawang merah varietas lokal. Meskipun demikian, bawang merah varietas lokal ini dinilai lebih tahan terhadap serangan hama bawang merah dan mudah beradaptasi dengan lingkungan (Basuki, 2005).

Peningkatan pertumbuhan dan produksi bawang merah bisa dilakukan dengan menambahkan unsur hara makro ke tanaman misalnya unsur nitrogen $(\mathrm{N})$. Unsur $\mathrm{N}$ bisa didapatkan dari pupuk yang diberikan ke tanaman. Banyak petani yang menggunakan pupuk anorganik karena dirasa pupuk ini lebih efektif menyuburkan tanaman dan mudah didapatkan di toko pertanian. Menurut Dewanto dkk., (2013) penggunaan pupuk anorganik selalu diikuti 
dengan masalah lingkungan, baik terhadap kesuburan biologis maupun kondisi fisik tanah serta berdampak pada konsumen karena produk pertanian yang banyak mengandung bahan kimia. Oleh karena itu diperlukan upaya mengganti penggunaan pupuk anorganik dengan pupuk organik yang aman untuk lingkungan yaitu salah satunya dengan menerapkan pertanian berbasis pertanian organik. Menurut Dlamini and Kongolo (2014) pertanian organik merupakan teknik budidaya pertanian yang mengandalkan bahanbahan alami tanpa menggunakan bahanbahan sintetis.

Persyaratan untuk pertanian yang lebih ramah lingkungan dan risiko masa depan yang timbul dari perubahan iklim semuanya terkait dengan kebutuhan mendesak untuk meningkatkan efisiensi penggunaan $\mathrm{N}$ pada tanaman (Zhang et al., 2015). Oleh karena itu perlu adanya pembaruan pemberian unsur $\mathrm{N}$ pada tanaman yaitu salah satunya dengan menggunakan plasma lucutan pijar korona. Menurut Komariyah (2003) penyinaran berkas ion nitrogen menggunakan plasma lucutan pijar korona ke dalam suatu bahan dapat merubah strukur mikro bahan sehingga merubah sifat - sifat fisik dan kimia bahan tersebut. Selain itu, penyinaran menggunakan plasma mampu menyediakan unsur nitrogen yang siap digunakan oleh tanaman secara langsung.
Penelitian yang dilakukan oleh Nurbuwati (2005) yang menyebutkan bahwa lucutan pijar korona dalam usaha pemuliaan benih dapat meningkatkan kualitas perkecambahan biji tanaman sawi. Menurut Nucifera et al., (2016) bahwa radiasi plasma mampu memberikan efek pertumbuhan kacang kedelai hitam yang hasilnya optimal pada penyinaran 30 menit yaitu pada parameter waktu tumbuh, tinggi tanaman, dan jumlah daun. Selain itu menurut Puspitasari (2018) dengan adanya penyinaran plasma maka kualitas dan tingkat produksi bibit bawang merah varietas Bima Brebes menjadi lebih baik dibandingkan dengan bibit bawang merah yang tidak disinari dengan plasma. Lama penyinaran 15 menit merupakan waktu yang optimal untuk menghasilkan tanaman bawang merah yang memiliki tinggi tanaman, kandungan klorofil, dan tingkat produksi yang tinggi pada penelitian ini. Akan tetapi pada penelitian ini belum digunakan tambahan pupuk kandang kambing untuk meningkatkan pertumbuhan dan produksi tanaman bawang merah. Oleh karena itu pada penelitian ini digunakan pupuk kandang kambing sebagai sumber unsur hara lainnya selain dari plasma lucutan pijar korona. Pupuk kandang kambing dipilih karena pupuk ini mengandung banyak unsur hara dibandingkan dengan pupuk kandang lainnya. Menurut Rahmawati 
Anitasari, E., Prihastanti, E., dan Arianto, F. Pengaruh Radiasi Plasma dan Pupuk andang Kambing Pertumbuhan Bawang Merah Varietas Bima Brebes

(2014) pupuk kandang kambing memiliki kandungan C-organik yang lebih tinggi dibandingkan C-organik pupuk kandang ayam, dengan adanya C-organik yang cukup maka dapat menggemburkan tanah sehingga penyerapan unsur hara dalam tanah akan maksimal.

Penelitian ini bertujuan untuk mengetahui pengaruh pemberian plasma lucutan pijar korona dan pupuk kandang kambing terhadap bibit bawang merah varietas Bima Brebes. Oleh karena itu diharapkan dapat meningkatkan dan mempercepat pertumbuhan bawang merah.

\section{METODE PENELITIAN}

Alat yang digunakan untuk penyinaran yaitu seperangkat alat plasma lucutan pijar korona yang terdiri dari osciloscope, sumber tegangan DC, elektroda bidang dan elektroda titik. Alat untuk uji kandungan klorofil total yaitu spektrofotometer UV-Vis, mortar dan pastle, corong, tabung reaksi, dan cuvet. Sedangkan untuk bahan yang digunakan yaitu bibit bawang merah varietas Bima Brebes (Allium cepa L.) yang dibeli di Pasar Rejowinangun Magelang, polybag, media tanam, pupuk kandang kambing siap pakai yang dibeli di Toko Suka Tani Magelang, aseton $80 \%$, aquades, aluminium foil, kertas label dan kertas saring.
Penelitian ini menggunakan

Rancangan Acak Lengkap (RAL) dengan pola faktorial. Faktor yang digunakan pada penelitian ini yaitu rentang waktu radiasi plasma (0 menit, 15 menit, dan 30 menit) dan jumlah pupuk kandang kambing $(0 \mathrm{~g}$, $32,5 \mathrm{~g}$, dan $65 \mathrm{~g}$ ). Penggunaan dosis pupuk tersebut bertujuan untuk mengurangi pemakaian pupuk didalam lahan pertanian. Oleh karena itu pada penelitian ini menggunakan 9 perlakuan dan 3 kali ulangan. Langkah penelitian yang dilakukan yaitu sebagai berikut :

1. Pemberian radiasi plasma

Pemberian radiasi plasma diawali dengan menyusun alat plasma. Kemudian bibit bawang merah varietas Bima Brebes ditimbang dan dipilih yang ukurannya seragam. Kemudian bibit tersebut diletakkan di elektroda bidang pada alat plasma. Jarak antara elektroda bidang dengan elektroda titik yaitu $3 \mathrm{~cm}$. Setelah itu alat plasma dihidupkan dengan menekan tombol power pada sumber DC dan mengatur arus serta tegangan listriknya. Arus dan tegangan listrik yang digunakan yaitu 1 $\mathrm{mA}$ dan $14 \mathrm{kV}$. Kemudian bibit bawang merah didiamkan selama 7 hari.

2. Persiapan media tanam

Media tanam yang digunakan yaitu tanah, arang sekam, dan pupuk kompos dengan perbandingan 1:1:1. Kemudian media tanam ini juga diberi perlakuan 
berupa ditambahkan pupuk kandang kambing sebanyak $0 \mathrm{~g}, 32,5 \mathrm{~g}$, dan $65 \mathrm{~g}$. Campuran media ini dimasukkan ke dalam polybag yang berukuran $15 \times 25$ $\mathrm{cm}$.

\section{Penanaman}

Proses penanaman dilakukan dengan cara memotong $1 / 3$ bagian dari ujung bibit bawang merah yang bertujuan untuk mempercepat proses tumbuhnya tunas. Setelah itu, bibit dibenamkan ke dalam media tanam tetapi tidak sampai terbenam semua. Lalu memberi label nama pada tiap polybag agar memudahkan pengamatan dan pengambilan data.

4. Pemeliharaan

Pemeliharaan penanaman bawang merah dilakukan melalui penyiraman dan pemberian pupuk. Penyiraman dilakukan 2 hari sekali. Untuk pemberian pupuk kandang kambingnya dilakukan 3 kali pada media tanam yaitu 7 hari sebelum tanam, hari ke- 10 setelah tanam, dan hari ke- 30 setelah tanam.

5. Uji kandungan klorofil total

Uji klorofil total dilakukan saat tanaman berusia 3 minggu. Proses uji ini dilakukan dengan mengambil dan menimbang daun bawang merah sebanyak 0,1 g, kemudian dihaluskan dan diekstraksi menggunakan aseton
80\%. Hasil ekstraksi kemudian disaring dan diukur kandungan klorofilnya menggunakan spektrofotometer UV-Vis dengan panjang gelombang 645 dan 663. Rumus menghitung kandungan klorofil total yaitu sebagai berikut: Klorofil total $\mathrm{mg} / \mathrm{g}$ berat daun $=8,02 \mathrm{x}$ $\mathrm{A} 663+20,2 \times \mathrm{A} 645 \times 10^{-1}$

6. Parameter pengukuran

Parameter yang diamati antara lain waktu tumbuh tunas, panjang akar, jumlah akar, tinggi tanaman, jumlah daun, dan jumlah kandungan klorofil total.

7. Pengamatan

Penanaman bibit bawang merah dilakukan selama 1 bulan. Pengamatan dilakukan 1 minggu sekali dengan mengukur tinggi tanaman dan jumlah daunnya. Setelah 1 bulan tanaman dicabut dengan hati - hati agar tidak merusak bagian akar dan umbinya karena kedua bagian tersebut kemudian diamati dengan cara dihitung jumlah akarnya dan diukur panjang akarnya. Untuk parameter waktu tumbuh tunas diamati pada $h+7$ setelah penanaman dan untuk parameter kandungan klorofil total dilakukan setelah tanaman berusia lebih dari 3 minggu. 
Anitasari, E., Prihastanti, E., dan Arianto, F. Pengaruh Radiasi Plasma dan Pupuk andang Kambing Pertumbuhan HASIL DAN PEMBAHASAN

Menurut hasil penelitian yang Oleh karena itu, bisa dikatakan bahwa didapatkan dapat diketahui bahwa untuk melakukan pertumbuhan maka pemberian plasma dan pupuk kandang bawang merah memiliki tingkat kambing yang terlalu banyak, terlalu kebutuhan unsur hara dengan takaran sedikit, ataupun tidak sama sekali tidak tertentu dan tidak boleh berlebihan mampu memberikan pertumbuhan ataupun kekurangan. (Tabel 1.) bawang merah yang baik dan optimal.

Tabel 1. Rata-rata Hasil PenelitianYang Sudah Diuji Anova

\begin{tabular}{|c|c|c|c|c|c|c|c|c|c|}
\hline \multirow{2}{*}{ Parameter } & \multicolumn{9}{|c|}{ Perlakuan } \\
\hline & POMO & P1M0 & P2M0 & P0M1 & P1M1 & P2M1 & P0M2 & P1M2 & P2M2 \\
\hline $\begin{array}{l}\text { Tumbuh Tunas } \\
\text { (hari) }\end{array}$ & 10 & 7 & 8 & 11 & 3,33 & 5 & 7,67 & 3,67 & 3,33 \\
\hline Panjang Akar (cm) & 6,07 & 6,56 & 6,6 & 5,57 & 7,7 & 6,9 & 7,67 & 10 & 9,33 \\
\hline Jumlah Akar & 20,33 & 21,33 & 22,33 & 24,33 & 26,67 & 25 & 30,67 & 33,67 & 31,67 \\
\hline $\begin{array}{l}\text { Tinggi Tanaman } \\
\text { (cm) }\end{array}$ & $30,9^{c}$ & $29,3^{c}$ & $38,27^{a}$ & $33^{\mathrm{bc}}$ & $39,07^{a}$ & $37 \mathrm{ab}$ & $32,57 \mathrm{bc}$ & $30,83^{c}$ & $40,47^{\mathrm{a}}$ \\
\hline Jumlah Daun (helai) & 12 & 13 & 13 & 14,33 & 16,33 & 13,67 & 13 & 15 & 14,33 \\
\hline $\begin{array}{l}\text { Kandungan Klorofil } \\
\text { Total (mg/g) } \\
\end{array}$ & 2,67 & 2,86 & 2,85 & 2,95 & 3,22 & 2,98 & 3,13 & 3,69 & 3,35 \\
\hline
\end{tabular}

Keterangan :

Angka yang diikuti huruf menunjukkan adanya interaksi dari kedua faktor perlakuan yang diberikan pada penelitian ini.

P0M0 = Plasma Lucutan Pijar Korona 0 menit + Pupuk Kandang Kambing 0 g (kontrol)

P1M0 = Plasma Lucutan Pijar Korona 15 menit + Pupuk Kandang Kambing 0 g

P2M0 = Plasma Lucutan Pijar Korona 30 menit + Pupuk Kandang Kambing 0 g

P0M1 = Plasma Lucutan Pijar Korona 0 menit + Pupuk Kandang Kambing 32,5 g

P1M1 = Plasma Lucutan Pijar Korona 15 menit + Pupuk Kandang Kambing 32,5 g

P2M1 = Plasma Lucutan Pijar Korona 30 menit + Pupuk Kandang Kambing 32,5 g

P0M2 = Plasma Lucutan Pijar Korona 0 menit + Pupuk Kandang Kambing 65 g

P1M2 = Plasma Lucutan Pijar Korona 15 menit + Pupuk Kandang Kambing 65 g

P2M2 = Plasma Lucutan Pijar Korona 30 menit + Pupuk Kandang Kambing 65 g

Tabel 2. Hasil Uji DMRT

\begin{tabular}{|c|c|c|c|c|c|c|}
\hline \multirow{2}{*}{ Parameter } & \multicolumn{6}{|c|}{ Hasil Uji DMRT } \\
\hline & PO & P1 & P2 & MO & M1 & M2 \\
\hline Tumbuh Tunas (hari) & $9,55^{\mathrm{a}}$ & $4,66^{b}$ & $5,44^{\mathrm{b}}$ & $8,33^{\mathrm{a}}$ & $6,44^{\mathrm{b}}$ & $4,88^{b}$ \\
\hline Panjang Akar (cm) & $6,43^{a}$ & $8,08^{a}$ & $7,61^{\mathrm{a}}$ & $6,41^{\mathrm{b}}$ & $6,72^{\mathrm{b}}$ & $9^{a}$ \\
\hline Jumlah Akar & $25,11^{\mathrm{a}}$ & $27,22^{\mathrm{a}}$ & $26,33^{\mathrm{a}}$ & $21,33^{c}$ & $25,33^{b}$ & $32^{\mathrm{a}}$ \\
\hline Tinggi Tanaman $(\mathrm{cm})$ & $32,16^{b}$ & $33,07^{b}$ & $38,57^{a}$ & $32,84^{b}$ & $36,35^{a}$ & $34,62^{\mathrm{ab}}$ \\
\hline Jumlah Daun (helai) & $13,11^{b}$ & $14,77^{\mathrm{a}}$ & $13,66^{\mathrm{ab}}$ & $12,66^{\mathrm{b}}$ & $14,77^{\mathrm{a}}$ & $14,11^{\mathrm{ab}}$ \\
\hline $\begin{array}{c}\text { Kandungan Klorofil } \\
\text { Total (mg/g) }\end{array}$ & $2,91^{\mathrm{a}}$ & $3,25^{\mathrm{a}}$ & $3,06^{\mathrm{a}}$ & $2,79^{b}$ & $3,05^{\mathrm{ab}}$ & $3,38^{a}$ \\
\hline
\end{tabular}

Keterangan :

Angka yang diikuti huruf yang sama pada baris yang sama menunjukkan pengaruh yang tidak berbeda nyata berdasarkan uji DMRT pada taraf kepercayaan 95\%.
$\mathrm{P} 0=$ radiasi 0 menit
$\mathrm{M} 0=$ pupuk $0 \mathrm{~g}$
$\mathrm{P} 1=$ radiasi 15 menit
M1 = pupuk 32,5 g
$\mathrm{P} 2$ = radiasi 30 menit
M2= pupuk $65 \mathrm{~g}$ 


\section{Tumbuh Tunas}

Hasil uji Anova menunjukkan bahwa perlakuan pemberian plasma lucutan pijar korona dan pupuk kandang kambing berpengaruh nyata terhadap waktu tumbuh tunas tanaman bawang merah. Selain itu, hasil ANOVA juga menunjukkan bahwa tidak ada interaksi dari kedua faktor perlakuan akan tetapi tiap faktornya memiliki pengaruh yang signifikan bagi waktu tumbuh tunas.

Hasil uji DMRT menunjukan bahwa pada parameter waktu tumbuh tunas, tanaman yang diberi perlakuan radiasi plasma dan media tanam yang ditambah pupuk kandang kambing menunjukkan hasil yang paling baik yaitu pada perlakuan P1M1 (plasma lucutan pijar korona 15 menit + pupuk kandang kambing 32,5 g) dan perlakuan P2M2 (plasma lucutan pijar korona 30 menit + pupuk kandang kambing 65 g). Hasil perlakuan P1M1 dan P2M2 menunjukkan waktu tumbuh yang lebih cepat yaitu 3,33 hari, sedangkan untuk perlakuan lain waktu tumbuh tunasnya lebih lama. Hasil tersebut menunjukkan adanya peningkatan pertumbuhan yang disebabkan oleh plasma dan pupuk kandang kambing yaitu sebesar 200,3\% lebih cepat dibandingkan dengan kontrol.

\section{Panjang Akar}

Hasil uji Anova menunjukkan bahwa perlakuan pemberian plasma lucutan pijar korona dan pupuk kandang kambing berpengaruh nyata terhadap panjang akar tanaman bawang merah. Selain itu, hasil ANOVA juga menunjukkan bahwa tidak ada interaksi dari kedua faktor perlakuan akan tetapi dari faktor media tanam yang diberi tambahan pupuk kandang kambing memiliki pengaruh yang signifikan pada parameter ini.

Hasil uji DMRT menunjukan bahwa pada parameter panjang akar, tanaman yang diberi perlakuan radiasi plasma dan media tanam yang ditambah pupuk kandang kambing menunjukkan hasil yang paling baik yaitu pada perlakuan P1M2 (plasma lucutan pijar korona 15 menit + pupuk kandang kambing 65 g). Hasil ini juga menunjukkan bahwa pemberian plasma dan pupuk kandang kambing mampu meningkatkan panjang akar sebesar 39,3\% dibandingkan dengan tanaman yang diberi perlakuan kontrol.

\section{Jumlah Akar}

Hasil uji Anova menunjukkan bahwa perlakuan pemberian plasma lucutan pijar korona dan pupuk kandang kambing berpengaruh nyata terhadap jumlah akar tanaman bawang merah. Selain itu, hasil ANOVA juga menunjukkan bahwa tidak ada interaksi dari kedua faktor perlakuan akan tetapi dari faktor media tanam yang diberi tambahan pupuk kandang kambing memiliki pengaruh yang signifikan pada parameter ini. 
Hasil uji DMRT menunjukan bahwa pada parameter jumlah akar, tanaman yang diberi perlakuan plasma lucutan pijar korona dan media tanam yang ditambah pupuk kandang kambing menunjukkan hasil yang paling baik yaitu pada perlakuan P1M2 (plasma lucutan pijar korona 15 menit + pupuk kandang kambing $65 \mathrm{~g})$. Hasil tersebut menunjukkan bahwa pemberian plasma dan pupuk kandang kambing mampu meningkatkan jumlah akar sebesar 39,62\% dibandingkan dengan perlakuan kontrol.

\section{Tinggi Tanaman}

Hasil uji Anova menunjukkan bahwa perlakuan pemberian plasma lucutan pijar korona dan pupuk dari kedua faktor perlakuan yang signifikan pada parameter ini. Hasil uji DMRT menunjukan bahwa pada parameter tinggi tanaman, tanaman yang diberi perlakuan plasma lucutan pijar korona dan media tanam yang ditambah pupuk kandang kambing menunjukkan hasil yang paling baik yaitu pada perlakuan P2M2 (plasma lucutan pijar korona 30 menit + pupuk kandang kambing 65 g). Hasil tersebut menunjukkan bahwa pemberian plasma dan pupuk kandang kambing mampu meningkatkan tinggi tanaman sebesar 23,57\% dibandingkan dengan perlakuan kontrol.

\section{Jumlah Daun}

Hasil uji Anova menunjukkan bahwa perlakuan pemberian plasma lucutan pijar korona dan pupuk kandang kambing berpengaruh nyata terhadap jumlah daun tanaman bawang merah. Selain itu, hasil ANOVA juga menunjukkan bahwa tidak ada interaksi dari kedua faktor perlakuan akan tetapi dari faktor media tanam yang ditambah pupuk kandnag kambing sendiri memiliki pengaruh yang signifikan pada parameter ini.Hasil uji DMRT menunjukan bahwa pada parameter jumlah daun, tanaman yang diberi perlakuan plasma lucutan pijar korona dan media tanam yang ditambah pupuk kandang kambing menunjukkan hasil yang paling baik yaitu pada perlakuan P1M1 (plasma lucutan pijar korona 15 menit + pupuk kandang kambing 32,5 g). Hasil ini menunjukkan bahwa pemberian plasma dan pupuk kandang kambing mampu meningkatkan jumlah daun sebesar $26,52 \%$.

\section{Kandungan Klorofil Total}

Hasil uji Anova menunjukkan bahwa perlakuan pemberian plasma lucutan pijar korona dan pupuk kandang kambing berpengaruh nyata terhadap kandungan klorofil total pada tanaman bawang merah. Selain itu, hasil ANOVA juga menunjukkan bahwa tidak ada interaksi dari kedua faktor perlakuan akan tetapi dari faktor media tanam yang ditambah pupuk kandnag kambing sendiri memiliki 
pengaruh yang signifikan pada kandungan klorofil total.

Hasil uji DMRT menunjukan bahwa pada parameter kandungan klorofil total, tanaman yang diberi perlakuan plasma lucutan pijar korona dan media tanam yang ditambah pupuk kandang kambing menunjukkan hasil yang paling baik yaitu pada perlakuan P1M2 (plasma lucutan pijar korona 15 menit + pupuk kandang kambing 65 g). Hasil penelitian ini menunjukkan bahwa pemberian plasma dan pupuk kandang kambing mampu meningkatkan kandungan klorofil total sebesar 26,64\% dibandingkan dengan tanaman kontrol.

Berdasarkan hasil penelitian yang didapatkan dapat diketahui bahwa rata rata perlakuan paling baik menghasilkan pertumbuhan bawang merah varietas Bima Brebes yaitu pada perlakuan P1M2 (plasma 15 menit + pupuk kandang kambing 65 g). Kemudian diikuti dengan perlakuan P1M1 (plasma 15 menit + pupuk kandang kambing 32,5 g) dan perlakuan P2M2 (plasma 30 menit + pupuk kandang kambing 65 g). Hasil penelitian ini menunjukkan bahwa pemberian plasma lucutan pijar korona dan pupuk kandang kambing mampu meningkatkan ketersediaan unsur hara dalam tanaman khususnya unsur nitrogen. Menurut Salim (2016) nitrogen merupakan unsur hara esensial yang tersedia bagi tanaman dalam bentuk $\mathrm{NH}_{4}{ }^{+}$dan $\mathrm{NO}_{3}^{-}$yang berfungsi untuk menyusun klorofil, protoplasma, asam nukleat dan asam amino. Razaq et al., (2017) menyebutkan bahwa nitrogen merupakan unsur hara penentu penting pada pertumbuhan dan produktivitas tanaman. Pertumbuhan tanaman dan morfologi akar merupakan parameter penting untuk mengevaluasi efek nutrisi yang disuplai.

Berdasarkan hasil penelitian yang didapatkan dapat diketahui bahwa pertumbuhan tanaman yang diberi perlakuan plasma dan pupuk kandang kambing hasilnya lebih baik dibandingkan dengan tanaman kontrol. Hasil terbaik didapatkan pada perlakuan penyinaran plasma seama 15 menit. Menurut Puspitasari (2018) waktu penyinaran yang optimal untuk pertumbuhan tanaman bawang merah tanpa diberi pupuk kandang kambing yaitu 15 menit dimana pada penelitian tersebut pada perlakuan bibit yang disinari selama 15 menit menunjukkan data tinggi tanaman dan kandungan klorofil total yang lebih baik dibandingkan dengan waktu penyinaran 0 menit dan 30 menit dengan prosentase sebesar 8,7\% dan 21,1\%. Penelitian yang dilakukan oleh Nur dkk., (2013) menunjukkan bahwa plasma lucutan pijar korona mampu mempercepat $43 \%$ proses pertumbuhan pada persemaian biji mangrove. 
Media tanam yang ditambah pupuk kandang kambing menunjukkan hasil yang baik pada dosis $65 \mathrm{~g}$ dimana dosis ini merupakan dosis dengan ukuran setengah dari dosis yang biasa digunakan oleh para petani sehingga apabila hasilnya baik maka penelitian ini berhasil mengurangi penggunaan pupuk yang terlalu banyak pada budidaya bawang merah. Firmansyah et al., (2015) menyebutkan bahwa pada lahan 1 ha tanah yang ditanami bawang merah itu biasanya membutuhkan 20 ton pupuk organik. Jarak tanam bawang merah biasanya $15 \times 25 \mathrm{~cm}$ sehingga dapat diketahui bahwa dalam 1 ha lahan bisa menampung 150.000 tanaman bawang merah. Oleh karena itu dapat diperoleh data bahwa satu tanaman itu membutuhkan pupuk organik kurang lebih $130 \mathrm{~g}$.

Menurut Ruhnayat (2007) setiap jenis tanaman membutuhkan unsur hara dalam jumlah yang berbeda. Ketidaktepatan pemberian unsur hara selain akan menyebabkan tanaman tidak dapat tumbuh dan berproduksi secara optimal juga merupakan pemborosan tenaga dan biaya (tidak efisien). Hal tersebut didukung oleh pendapat Jahan et al., (2016) yang mengatakan bahwa media tanam dengan kandungan unsur hara yang tepat mampu memberikan pengaruh baik bagi pertumbuhan tanaman.
Parameter penelitian yang paling menunjukan adanya pengaruh radiasi plasma lucutan pijar korona yaitu pada parameter tumbuh tunas. Bawang merah yang diberi perlakuan penyinaran plasma 30 menit lebih cepat tumbuh akarnya dibandingkan dengan yang disinari 15 menit atau tidak disinari. Hal ini terlihat pada saat bawang merah yang telah disinari plasma didiamkan selama 1 minggu menunjukan perbedaan ciri fisik yaitu dengan munculnya akar. Hal ini sesuai dengan pendapat Jahan et al., (2016) bahwa teknologi plasma mampu mempercepat pertumbuhan akar tanaman dan Muhlisin dkk., (2005) menyebutkan bahwa teknologi plasma yang disinarkan ke biji jagung BISI-2 memberikan efek perkecambahan yang cepat bagi tanaman jagung.

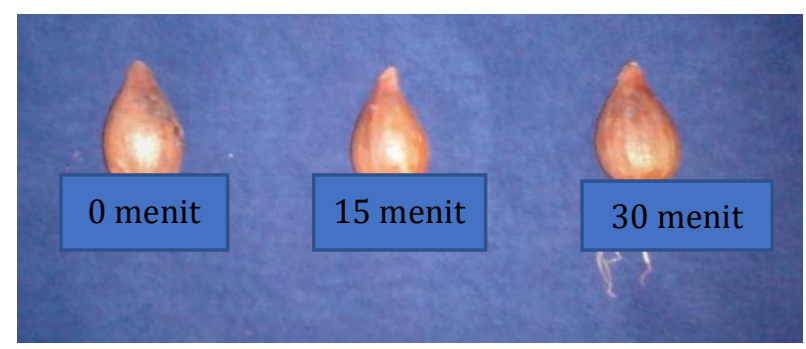

Gambar 1. Perbedaan ciri fisik bibit yag muncul setelah diberikan radiasi plasma dan didiamkan selama 1 minggu

\section{SIMPULAN}

Berdasarkan penelitian yang dilakukan maka dapat disimpulkan bahwa pemberian plasma lucutan pijar korona dan pupuk kandang kambing mampu meningkatkan dan mempercepat 
pertumbuhan tanaman bawang merah varietas Bima Brebes. Perlakuan paling optimal didapatkan pada P1M2 (plasma 15 menit dan pupuk kandang kambing 65 g). Selain itu, pemberian plasma pada tanaman mampu mengurangi penggunaan pupuk sehingga mampu memperbaiki kondisi tanah yang jenuh dengan bahan kimia.

\section{UCAPAN TERIMA KASIH}

Penulis mengucapkan terima kasih kepada seluruh staff laboratorium Center for Plasma Research dan laboratorium Biologi Struktur dan Fungsi Tumbuhan Universitas Diponegoro atas dukungan dan keikutsertaan dalam kegiatan ilmiah ini.

\section{DAFTAR PUSTAKA}

Basuki, S. 2005. Daya Hasil dan Preferensi Petani terhadap Varietas Bawang Merah Lokal dari Berbagai Daerah. Laporan Hasil Penelitian $A P B N$ 2005-ROPP DI.

Darwis V., I. B. 2004. Keragaman Benih Hortikultura Di Tingkat Produsen dan Konsumen (Studi Kasus: Bawang Merah, Cabai Merah, Kubis, dan Kentang). SocioEconomic of Agriculturre and Agribusiness 4(2): 1-18.

Dewanto, F. G., J.J.M.R. Londok, R.A.V. Tuturoong dan W. B. Kaunang. 2013. Pengaruh Pemupukan Anorganik dan Organik Terhadap Produksi Tanaman Jagung Sebagai Sumber Pangan. Jurnal Zootek. Vol. 32. No. 5. ISSN 0852-2626.

Direktorat Jenderal Hortikultura. 2018. Laporan Kinerja Direktorat Jenderal Hortikultura TA.2017. Jakarta: Kementerian Pertanian Direktorat Jenderal Hortikultura.

Dlamini, D. F., and Kongolo, M. 2014. Resource Use Efficiency in Organic Vegetable Production: A Case Study of Manzini Region, Swaziland. Journal of Agricultural Studies. 2(2): 52 .
Erytrina. 2013. Perbenihan Dan Budidaya Bawang Merah. Seminar Nasional Inovasi Teknologi Pertanian Mendukung Ketahanan Pangan Dan Swasembada Beras Berkelaanjutan di Sulawesui Utara. Bogor : Balai Besar Pengkajian Dan Pengembangan Teknologi Pertanian.

Firmansyah, I., Liferdi, Khaririyatun, N, dan Yufdy, MP. 2015. Pertumbuhan dan Hasil Bawang Merah dengan Aplikasi Pupuk Organik dan Pupuk Hayati pada Tanah Alluvial. J. Hort. 25(2) : 133-141.

Jahan, S.L. et.al. 2016. Role of Nitrogen for Plant Growth and Development: A Review. Advances in Environmental Biology. AENSI Journals. 10 (9) : 209-218.

[Kemendag] Kementerian Perdagangan. 2019. Harga dan Pasokan Bawang merah Brebes Di Lokasi Perdagangan Utama. https://ews.kemendag.go.id/bawangmerah/ DailyPriceBawang.aspx\#1. Diakses tanggal 25 April 2019.

Komariyah. 2003. Dekontaminasi Bakteri Escherichia coli dengan Plasma Lucutan Pijar Korona Pada Tekanan Atmosfer. Skripsi. DepartemenFisika. Fakultas Sains dan Matematika Universitas Diponegoro, Semarang.

Muhlisin, Z., Triadyaksa, Pandji dan W. Jafron. 2005. An Increase in The Quality and Quantity of Production of Corn (Zea mays) Through Infiltration $\mathrm{N}^{+}$Using Discharge Plasma Generator System Flare Corona. Reports. Dikrutin Programs University of Diponegoro.

Nana, S. A., dan Salamah, Z. 2014. Pertumbuhan Tanaman Bawang Merah (Allium cepa L.) dengan Penyiraman Air Kelapa (Cocos nucifera L.) Sebagai Sumber Belajar Biologi SMA Kelas XII. JUPEMASI-PBIO. Vol. 1 No. 1.

Nucifera, N., Kanie, M. A., Pratiwi, S. H., Pratiwi, R., Putro, S. P., and Nur, M. 2016. Corona Discharge Plasma Technology to Accelerate the Growth of Black Soybean Plants. Journal of Natural Sciences Research . ISSN 22243186. Vol 6. No 14.

Nurbuwati. 2005. Pengaruh Radiasi Plasma Lucutan Pijar Terhadap Perkecambahan Biji Sawi Pada Tekanan Atmosfer. Skripsi. Departemen Fisika. Fakultas Sains dan Matematika Universitas Diponegoro, Semarang.

Nur, M., Nasruddin, Wasiq J., dan Sumariyah. 2013. Penerapan Teknologi Plasma Untuk Mempercepat Persemaian Mangrove Sebagai Upaya Rehabilitasi Green Belt Untuk Mengatasi Abrasi. Riptek. 7 (1), 1526. 
Puspitasari, I. 2018. Respon Pertumbuhan dan Produksi Tanaman Bawang Merah (Allium сера L.) Akibat Perbedaan Lama Radiasi Plasma. Skripsi. Departemen Biologi Fakultas Sains dan Matematika Universitas Diponegoro, Semarang.

Rahmawati, D. 2014. Pengaruh Takaran Pupuk NPK dan Jenis Pupuk Kandang Terhadap Pertumbuhan dan Hasil Tanaman Tomat (Lycopersicon esculentum Mill.) Kultivar Tymoti. Jurnal Agropanthera 3 (1): 1-13.

Razaq M., P. Zhang, H. Shen, and Salahuddin. 2017. Influence Of Nitrogen and Phosphorous On The Growth and Root Morphology Of Acer mono.PLOS ONE. DOI:10.1371.
Ruhnayat, Agus. 2007. Penentuan Kebutuhan Pokok Unsur Hara N, P, K Untuk Pertumbuhan Tanaman Panili (Vanilla planifolia Andrews). Bul. Littro. Vol. XVIII No (1) : $49-59$.

Salim, A. 2016. Efektivitas Pupuk Organik Terhadap Produktivitas Tanaman Kakao di Sulawesi Tenggara. Jurnal Pengkajian dan Pengembangan Teknologi Pertanian. Vol 19. No 2. hal : 167-176.

Zhang X., Davidson E.A., Mauzerall D.L., Searchinger T.D., Dumas P., and Shen Y. 2015. Managing Nitrogen for Sustainable Development. Nature 528 :51-59. 